Klinikal Sains 9 (2) (2021)
KURNAL ANALIS KESEHATAN
KLINIKAL SAINS
UNIVERSITAS
ABDURRAB

\title{
UJI DIAGNOSTIK PEMERIKSAAN NITRIT DENGAN KULTUR URIN PADA SUSPEK INFEKSI SALURAN KEMIH
}

\author{
Putra Rahmadea Utami, Mita Ayu Oktafiani \\ Program Studi Teknologi Laboratorium Medik, Fakultas Ilmu Kesehatan, Universitas Perintis \\ Indonesia
}

Alamt Email : putrarahmadeautami123@gmail.com

\begin{tabular}{|c|c|}
\hline Info Artikel & Abstrak \\
\hline $\begin{array}{l}\text { Sejarah Artikel: } \\
\text { Diterima November } 2021 \\
\text { Disetujui Desember } 2021 \\
\text { Dipublikasikan Desember } \\
2021\end{array}$ & $\begin{array}{l}\text { Infeksi saluran kemih (ISK) merupakan infeksi terbesar kedua } \\
\text { setelah infeksi pernafasan dan dapat menyebabkan sepsis. Infeksi } \\
\text { saluran kemih terjadi karena adanya proses masuknya } \\
\text { mikroorganisme pada saluran kemih. Saluran kemih yang biasa } \\
\text { terinfeksi yaitu antara lain uretra (urethritis), kandung kemih } \\
\text { (cystisis), ureter (ureteristis), jaringan ginjal (pyelonephritis). } \\
\text { Penelian ini bertujuan Untuk menetukan sensitivitas dan spesifisitas } \\
\text { pada uji diagnostik pemeriksaan nitrit dengan kultur urine pada } \\
\text { suspek infeksi saluran kemih. Metode penelitian ini adalah studi } \\
\text { deskriptif-Analitik dengan pendekatan cross-sectional study, } \\
\text { dilakukan di laboratorium STIKes padang dengan populasi yang } \\
\text { diteliti dalam penelitian ini adalah seluruh pasien yang terdiagnosa } \\
\text { mengalami infeksi saluran kemih dengan besar sampel } 50 \text { sampel. } \\
\text { Hasil dari penelitian ini didapatkan hasil nitrit posistif sebanyak } 17 \\
\text { orang persentasi } 34 \% \text {, dan hasil nitrit negatif sebanyak } 33 \text { orang } \\
\text { dengan persentasi } 66 \% \text { dan Pada pemeriksaan kultur urin didapatkan } \\
\text { hasil positif sebanyak } 17 \text { orang dengan persentase } 34 \% \text {, dimana hasil } \\
\text { pertumbuhan koloni bakteri pada biakan >100.000 CFU/mL dan } \\
\text { hasil negatif sebanyak } 33 \text { orang dengan persentase } 66 \% \text {. Hasil } \\
\text { Sensitifitas } 82 \%, \text { Spesifisitas 90,9 \%. Kesimpulan dari penelitian ini } \\
\text { dari nilai Sensitifitas, Spesifisitas yang tinggi maka uji nitrit dengan } \\
\text { kultur urin dapat di terapkan untuk membantu diagnosis ISK. }\end{array}$ \\
\hline
\end{tabular}


Kata Kunci : Infeksi Saluran Kemih, Nitrit, Kultur Urin

\section{Abstract}

Urinary tract infection (UTI) is the second largest infection after respiratory infection and can cause sepsis. Urinary tract infections occur due to the entry of microorganisms in the urinary tract. The urinary tract that is usually infected is the urethra (urethritis), bladder (cystisis), ureter (ureteristis), kidney tissue (pyelonephritis). This study aims to determine the sensitivity and specificity of the diagnostic test of nitrite examination with urine culture in suspected urinary tract infections. The method of this study is a descriptiveanalytical study with a cross-sectional retrospective approach, conducted in the STIKes field laboratory with the population studied in this study were all patients diagnosed with urinary tract infection with a sample size of 50 samples. The results of this study showed positive nitrite results as many as 17 people, 34\% percentage, and negative nitrite results as many as 33 people with a percentage of $66 \%$ and on urine culture examination obtained positive results as many as 17 people with a percentage of $34 \%$, which results in growth of bacterial colonies on cultures>100,000 CFU / mL and negative results of 33 people with a percentage of $66 \%$. Sensitivity Results $82 \%$, Specificity $90.9 \%$. The conclusion of this study is the value of sensitivity, high specificity so that the nitrite test with urine culture can be applied to help diagnose UTI.

Keywords : :Urinary Tract Infection, Nitrite, Urine Culture

(C) 2021

Universitas Abdurrab

Alamat korespondensi:

ISSN 2338-4921

Program Studi Teknologi Laboratorium Medik,

Fakultas Ilmu Kesehatan, Universitas

PerintisIndonesia

Email : putrarahmadeautami123@gmail.com

\section{PENDAHULUAN}


Infeksi saluran kemih (ISK) merupakan infeksi terbesar kedua setelah infeksi pernafasan dan dapat menyebabkan sepsis. Infeksi saluran kemih terjadi karena adanya proses masuknya mikroorganisme pada saluran kemih. Saluran kemih yang biasa terinfeksi yaitu antara lain uretra (urethritis), kandung kemih (cystisis), ureter (ureteristis), jaringan ginjal (pyelonephritis). Untuk menegakkan diagnosis ISK harus ditemukan bakteri dalam urin melalui biakan atau kultur dengan jumlah signifikan. Tingkat signifikan jumlah bakteri dalam urin lebih besar dari 100/ml urin. Bakteri penginfeksian yang paling sering adalah Escheria coli, Proteus Sp, Klebsiella Sp, Serratia, Pseudomonas Sp (Utami et al., 2021)

Menurut WHO, infeksi saluran kemih (ISK) adalah penyakit infeksi yang kedua sering di temukan pada tubuh sesudah infeksi saluran pernapasan, sebanyak 8.3 juta kasus di laporkan per tahun. ISK dapat mengenai baik pria maupun wanita dari semua umur baik anak-anak, remaja, dewasa maupun lanjut usia. Data penelitian epidemiologi klinik melaporkan sebanyak 25-35\% wanita dewasa pernah mengalami ISK selama hidupnya Sekitar 50\% (Fitricilia et al., 2013)

Menurut Departemen Kesehatan Republik Indonesia, jumlah kasus penderita ISK di Indonesia adalah 90-100 kasus per 100.000 penduduk pertahunnya atau sekitar 180.000 kasus baru pertahun. Diperkirakan hampir 10 juta penduduk yang datang ke dokter untuk memeriksakan kesehatannya adalah pasien suspek infeksi saluran kemih(ISK) dan wanita 50 kali lebih banyak teridentifikasi dibandingkan laki-laki, yakni 2 dari 10 wanita mengalami ISK dibandingkan laki-laki. (Sari, 2018)

Penyebabnya adalah saluran-saluran uretra (saluran yang menghubungkan kantung kemih kelingkungan luar tubuh) milik perempuan lebih pendek yakni sekitar 3-5 cm sehingga bakteri dari rektum dapat dengan mudah masuk dan menyebabkan infeksi, Infeksi saluran kemih terdiagnosis apabila terdapat lebih dari $100.000 \mathrm{CFU} / \mathrm{ml}$ atau $10^{5} \mathrm{CFU} / \mathrm{ml}$ bakteri berspesies sama per liter urin Pemeriksaan laboratorium sangat penting dalam membantu menegakkan diagnosis ISK. Uji uranilisis merupakan salah satu pemeriksaan laboratorium yang penting untuk menegakkan berbagai diagnosis salah satunya pemeriksaan ISK. Untuk mendiagnosis ISK dapat menggunakan berbagai metode.(Darsono et al., 2016)

Pemeriksaan urin makroskopik adalah analisa urin yang dilihat dengan mata langsung dan tidak memerlukan pemeriksaan di bawah mikroskop. Analisis makroskopik urin dilakukan dengan memeriksa penampilan fisik urin. Pemeriksaan makroskopik meliputi kejernihan dan warna, secara normal urin berwarna kuning muda dan jernih tanpa ada kekeruhan pada urin dan Sampel urine yang teridentifikasi ISK adalah berwarna pekat lalu terdapat kekeruhan pada urin. Hasil analisa dari pemeriksaan makroskopik dapat memberikan petunjuk penting untuk pemeriksaan selanjutnya (Fitricilia et al., 2013)

Tes nitrit urin adalah tes yang dapat digunakan untuk mengetahui ada tidaknya bakteri di dalam urin. Pemeriksaan urin dengan metode carik celup pada pemeriksaan nitrit dapat digunakan untuk mendiagnosis ISK secara skrining, serta mengetahui adanya bakteri di urin yang merubah nitrat (yang berasal dari makanan) menjadi nitrit dengan pertimbangan metode yang mudah dan yang terpenting adalah mendapatkan hasil uji ISK dengan waktu yang relatife cepat, Nilai rujukan adalah negatif, positif apabila terjadi perubahan warna menjadi pink pada carik celup, Jadi adanya nitrit dalam urin secara tidak langsung menunjukkan kemungkinan adanya bakteri dalam urin dalam jumlah yang bermakna (Triono \& Purwoko, 2012) 
Standar baku emas atau gold standar dari pemeriksaan ISK adalah kultur urin, Spesimen yang akan digunakan untuk pengkulturan urin ini berupa urin tengah pertama pagi, dan metode yang digunakan adalah meode dilusi dan metode tanpa pengenceran. Interpresentasi hasil kultur urine secara kualitatif berdasarkan jumlah kuman yang tumbuh pada media kultur .(Rahmadea Utami et al., 2020) Hasil dilaporkan berdasarkan jumlah bakteri yang tumbuh, kriteria ini sering digunakan untuk menunjukkan adanya bakteriuria, yaitu $\geq 10^{5} \mathrm{CFU} / \mathrm{Ml}$. kriteria ini terlihat dari adanya $>100$ koloni bakteri dimedia kultur walaupun tidak disertai dengan gejala. Pada Jumlah koloni $<10^{3} \mathrm{koloni} / \mathrm{ml}$ urine kemungkinan besar bakteri yang tumbuh hanya merupakan kontaminasi flora normal dari muara uretra.(Pratistha et al., 2018)

Penelitian uji diagnostik ini dilakukan untuk mengetahui sensitivitas dan spesifisitas pemeriksaan nitrit dengan kultur urin pada suspek infeksi saluran kemih .

\section{METODE PENELITIAN}

Jenis penelitian ini merupakan penelitian deskriptif Analitik studi dengan pendekatan cross-sectional study yaitu mengetahui prevelensi uji nitrit dengan kultur urin pada pasien terdiagnosa ISK. Penelitian ini telah dilakukan di Laboratorium Mikrobiologi Universitas Perintis Indonesia.

Populasi yang diteliti dalam penelitian ini adalah seluruh pasien melakukan pemeriksaan infeksi saluran kemih kelaboratorium di RSUP Dr. M.djamil Padang. Sampel pada penelitian ini menggunakan metode purposive sampling sebanyak 50 orang yang terdiagnosa mengalami infeksi saluran kemih yang memenuhi kriteria inklusi dan kriteria ekslusi di RSUP Dr. M.djamil Padang.

Analis data yang digunakaan dalam penelitian ini adalah Analisis Univariat yaitu dilakukan secara studi deskriptif Analitik dari masing-masing variabel dengan tabel distribusi frekuensi disertai penjelasan. Setelah data terkumpul, data didespresikan dan disajikan dalam bentuk tabel, untuk hasil nitrit dan hasil kultur urine pada pasien Infeksi saluran kemih dan di analisis dengan uji sensitivitas dan spesifisitas secara manual juga menggunakan alat bantu untuk memproses data statistik dengan perangkat lunak program SPSS 17.

\section{HASIL PENELITIAN}

Tabel 4.1 Karakteristik Umum Responden Berdasarkan Umur Dan Jenis Kelamin

\begin{tabular}{clc}
\hline Variabel & Jumlah (N) & $\%$ \\
\hline Jenis Kelamin & & \\
Laki-Laki & 19 & $38 \%$ \\
Perempuan & 31 & $62 \%$ \\
\hline Umur & & \\
$<12$ Tahun & 7 & $14 \%$ \\
21-40 Tahun & 1 & $2 \%$ \\
41-60 Tahun & 17 & $34 \%$ \\
$>$ 60 Tahun & 25 & $50 \%$ \\
\hline $\mathrm{N}$ & 50 & $100 \%$ \\
\hline
\end{tabular}


Berdasarkan Tabel 4.1 bahwa perempuan merupakan pasien dengan suspek infeksi saluran kemih terbanyak dibandingkan dengan laki-laki. Dimana pasien suspek infeksi saluran kemih yang berjenis kelamin perempuan sebanyak 31 Orang (62\%) dan laki-laki sebanyak 19 orang (38\%). Didapatkan hasil kategori umur >60 tahun merupakan pasien dengan suspek infeksi saluran kemih terbanyak dengan 25 orang $(50 \%)$.

\subsubsection{Nilai Diagnosis Nitrit Dengan Kultur Urin Sebagai Diagnosis Infeksi Saluran Kemih}

\begin{tabular}{llll}
\hline & \multicolumn{2}{c}{ Kultur } & \\
& Positif & Negatif & Total \\
\hline Nitrit & & & \\
Positif & 14 & 3 & 17 \\
Negatif & 3 & 30 & 33 \\
\hline $\mathrm{N}$ & 17 & 33 & 50 \\
\hline
\end{tabular}

Berdasarkan tabel 4.2 di dapatkan hasil sebagai berikut:

a) Sensitivitas

$(\mathrm{a} / \mathrm{a}+\mathrm{c}) \times 100 \%=82 \%$

b) Spesifisitas

$(\mathrm{d} / \mathrm{b}+\mathrm{d}) \times 100 \%=90,9 \%$

c) Akurasi

$(\mathrm{a}+\mathrm{d} / \mathrm{a}+\mathrm{b}+\mathrm{c}+\mathrm{d}) \times 100 \%=88 \%$

d) Positive predictive value $(\mathrm{a} / \mathrm{a}+\mathrm{b}) \times 100 \%=82 \%$

e) Negative predictive value $(\mathrm{d} / \mathrm{d}+\mathrm{c}) \times 100 \%=90,9 \%$

Berdasarkan tabel 4.2 didapatkan hasil sensitifitas $82 \%$ dapat diartikan bahwa pemeriksaan ISK menggunakan nitrit dengan kultur urin ini memiliki kemampuan medeteksi $82 \%$ dengan benar yang positif Infeksi saluran kemih. Dan didapatkan hasil spesifisitasnya 90,9\% , dan terbukti negatif ISK sebanyak 90,9\%.

Didapatkan hasil nilai akurasi dari pemeriksaan nitrit dengan kultur urin $88 \%$, Nilai ini mengukur derajat akurat pemeriksaan antara tes skrining yaitu pemeriksaan nitrit dan gold standar yaitu pemeriksaan kultur urin. Didapatkan hasil Predectiv Value Positif 82\%, Didapatkan hasil Predectiv Value Negatif 90,9\%.

\section{PEMBAHASAN}

\section{Distribusi Umum Responden Berdasarkan Umur Dan Jenis Kelamin}

Karakteristik umum dari hasil penelitian ini rerata umur responden adalah $3.30 \pm 1.147$ SD tahun ,dengan umur paling kecil 2 tahun dan paling besar 78 tahun. Untuk jenis kelamin sebagian besarnya (62\%) perempuan dibandingkan laki-laki yaitu (38\%). Hasil penelitian ini sesuai dengan penelitian lain, 
yaitu didapatkan angka kejadian ISK pada perempuan lebih banyak mengalami ISK dibandingkan lakilaki dengan proporsi 63 orang $(65,5 \%)$

Berdasarkan penelitian yang telah dilakukan, didapatkan kategori umur $>61$ tahun adalah kategori umur dengan suspek infeksi saluran kemih terbanyak yaitu 25 orang presentase (50\%) dari 50 sampel yang diperiksa, dan didapatkan kategori umur 21-40 tahun adalah kategori umur suspek infeksi saluran terendah yaitu sebanyak 1 orang dengan presentase (2\%), hal ini sesuai dengan penelitian sebelumnya menemukan bahwa kasus ISK paling banyak terjadi pada usia $>60$ tahun, Penelitian lain juga mendapatkan hasil yang hampir sama yaitu paling sering terjadi pada usia $>59$ tahun, sesuai dengan teori yang menyatakan bahwa ISK meningkat pada usia lanjut (Lansia).

\section{Nilai Uji Sensitivitas, Spesifisitas, uji diagnostik pemeriksaan nitrit dengan kultur urin pada suspek ISK}

Berdasarkan penelitian ini didapatkan nilai sensitivitas $82 \%$ yang artinya sebanyak $82 \%$ suspek infeksi saluran kemih dapat diagnosis dengan pemeriksaan nitrit dengan kultur urin. Sensitivitas menunjukkan kemampuan suatu tes untuk menyatakan positif pada orang-orang yang sakit, semakin tinggi sensitivitas suatu test maka semakin banyak mendapatkan hasil tes pada orang-orang sakit atau semakin sedikit jumlah negatif palsu yang didapatkan (Retno Dwi Hartantia, Nur Oktaviab, 2020)

Didapatkan nilai spesifisitas $90,0 \%$ yang artinya sebesar 90,9\% suspek infeksi saluran kemih negatif dapat didiagnosis menggunakan pemeriksaan nitrit dengan kultur urin. spesifisitas menunjukkan kemampuan suatu test untuk menyatakan negatif pada orang-orang yang tidak sakit. Dari beberapa penelitian yang dilakukan, tes nitrit mempumyai nilai spesifisitas yang lebih besar dari 90-100\%, semakin spesifisitas suatu test maka semakin banyak mendapatkan suatu test negatif pada orang-orang yang tidak sakit atau semakin sedikit jumlah positif palsu (McLellan \& Hunstad, 2016)

Didapatkan hasil predectiv value positif $82 \%$, dapat di artikan besarnya proporsi seseorang dengan hasil positif menderita penyakit sebesar $82 \%$, dan didapatkan hasil predectiv value negatif sebesar proporsi seseorang dengan tes negatif atau tidak menderita penyakit sebesar $90,9 \%$. Yang berarti kemungkinan seseorang benar-benar tidak sakit apabila hasil uji dignostiknya negatif Didapatkan nilai akurasi dari pemeriksaan nitrit dengan kultur urin $88 \%$, akurasi adalah proporsi hasil tes yang menyatakan benar (True Vellue) diantara semua yang diperiksa, nilai akurasi mengukur derajat akurat pemeriksaan antara tes skrining yaitu pemeriksaan nitrit dan gold standar yaitu pemeriksaan kultur urin, sebesar $88 \%$ hasil test dinyatakan benar (true vellue)(Endriani et al., 2012)

\section{KESIMPULAN}

Pada uji diagnostik pemeriksaan nitrit dengan kultur urin pada suspek infeksi saluran kemih didapatkan hasil sensitifitas $82 \%$, spesitifitas $90,9 \%$

\section{REFERENSI}


Darsono, P. V., Mahdiyah, D., \& Sari, M. (2016). Gambaran Karakteristik Ibu Hamil Yang Mengalami Infeksi Saluran Kemih (Isk) Di Wilayah Kerja Puskesmas Pekauman Banjarmasin. Dinamika Kesehatan Jurnal Kebidanan Dan Keperawatan, 7(1), 150-159.

Endriani, R., Andrini, F., \& Alfina, D. (2012). Pola Resistensi Bakteri Penyebab Infeksi Saluran Kemih (ISK) Terhadap Antibakteri di Pekanbaru. Jurnal Natur Indonesia, 12(2), 130. https://doi.org/10.31258/jnat.12.2.130-135

Fitricilia, M., Umboh, A., \& Kaunang, D. (2013). Hubungan Enuresis Dengan Infeksi Saluran Kemih Pada Anak Usia 6-8 Tahun Di Sd Negeri Malalayang. Jurnal E-Biomedik, l(1). https://doi.org/10.35790/ebm.1.1.2013.4582

McLellan, L. K., \& Hunstad, D. A. (2016). Urinary Tract Infection: Pathogenesis and Outlook. Trends in Molecular Medicine, 22(11), 946-957. https://doi.org/10.1016/j.molmed.2016.09.003

Pratistha, F. S. M., Sudhana, I. W., \& Adnyana, I. W. L. (2018). Diagnosis Cepat Infeksi Saluran Kemih Dengan Menghitung Jumlah Leukosituria Pada Urinalisis Metode Flowcytometry Sysmex Ux-2000 Dengan Baku Emas Kultur Urin Di Rsup Sanglah Denpasar. Jurnal Penyakit Dalam Udayana, 1(2), 52-56. https://doi.org/10.36216/jpd.v1i2.4

Rahmadea Utami, P., Chairani, \& Yudha, H. (2020). COMBINATION TEST OF CHINESE LEAF EXTRACT (Leucaena leucocephala folium) AND ALOE VERA INHIBITING GROWTH Escherichia coli. Indonesian Journal of Medical Laboratory Science and Technology, 2(2), 60-67. https://doi.org/10.33086/ijmlst.v2i2.1577

Retno Dwi Hartantia, Nur Oktaviab, A. D. S. S. F. (2020). CHMK PHARMACEUTICAL SCIENTIFIC JOURNAL CHMK PHARMACEUTICAL SCIENTIFIC JOURNAL I . LATAR BELAKANG Infeksi Saluran Kemih ( ISK ) merupakan infeksi akibat berkembang biaknya kasus baru pertahun . Berdasarkan laporan pola penyakit dari unit rekam medis RSUD S. Infeksi, Pasien Kemih, Saluran Instalasi, D I Inap, Rawat Soe, Rsud, 3(April).

Sari, R. P. (2018). Angka Kejadian Infeksi Saluran Kemih (ISK) Dan Faktor Resiko Yang Mempengaruhi Pada Karyawan Wanita Di Universitas Lampung Event Numbers Urinary Tract Infection (Uti) and Risk Factor that Affecting on Female Employees In University of Lampung. Majority, 7(3), 115120.

Triono, A. A., \& Purwoko, A. E. (2012). Efektifitas Antibiotik Golongan Sefalosporin dan Kuinolon terhadap Infeksi Saluran Kemih The. Mutiara Medika, 12(1), 6-11.

Utami, P. R., Indrayati, S., \& Hayatang, N. (2021). Ability of Ethanol Extract from Ajwa and Sukkari Dates (Phoenix dactylifera L.) in Inhibiting the Growth of Methicillin-Resistant Staphylococcus aureus (MRSA). Indonesian Journal of Medical Laboratory Science and Technology, 3(1), 1-8. https://doi.org/10.33086/ijmlst.v3i1.1848 